\title{
The Concept of Local Wisdom on the House Planning Prototype Specially for the State Border Officers in Sanggau Regency
}

\author{
Hakim $^{1}$, Tri Endangsi ${ }^{2}$ \\ \{hakim@budiluhur.ac.id ${ }^{1}$, tri.Endangsih@budiluhur.ac.id ${ }^{2}$ \} \\ Lecturer of Architecture Department Faculty of Engineering Universitas Budi Luhur, Jakarta, \\ Indonesia ${ }^{1,2}$
}

\begin{abstract}
The concept of local wisdom is seen from anthropological, historical, and particularly the field of architecture (built environment). Local wisdom is an element of the cultural traditions of people's society, which appear to be parts that are placed in the physical order of buildings (architecture) and the (urban) region in the geography of the nation. From his explanation, it can be seen that local wisdom is the application of tradition which substituted in physical artifacts. The concept of local wisdom that was very important to the preparation of this prototype is the uniformity of society buildings around the border region which as to not cause social jealousy in the society. In order to realize the Special House for State Border Officers in a healthy environment, safe, harmonious, and well-ordered as well as able to support a good housing, it is necessary to prepare the Prototype of Special House for state Border Officer as a reference in Physical building development that concern to quality, local support, the spatial layout of the region, and local wisdom. Therefore, it is necessary to formulate the Prototype of the Special at Border region as a reference of Design preparation/ Detail Engineering Design (DED) of special house at Border region that is appropriate, healthy, harmonious, and meet the need of the society as well as concern to spatial layout, environmental conditions and wisdom local premises.
\end{abstract}

Keywords: Local Wisdom, Special House, State Border.

\section{Introduction}

The border area is the entrance of a country, thus more attention is required. Development as well as facilities such as education, health, transportation, information and so forth should be sufficient. Communities in the border areas should be more concerned about their needs, so they are not isolated from the outside world. Improving the health condition of residential environments for the provision of healthy houses and the sanitation of household environments in border villages and border buffers; the management of reservoirs, ponds and other water reservoirs for the prevention of endemic diseases is of paramount importance in advancing communities in the border region.

The Border people in doing their duties is difficult to obtain a decent and affordable residence due to the rising of house prices and houses on the border are not yet available. To meet the needs of appropriate, healthy, and affordable residences for people at the State Border, The Government through the Ministry of Public Works and Public Housing 
encourages the building of Special house for citizen at the State Borders. It is hoped that the fulfillment of housing requirement for the citizen at the State border, it is able to improve the work performance, quality of life, and economy [1].

In order to realize the Special House for State Border Officers in a healthy environment, safe, harmonious, and well-ordered as well as able to support a good housing, it is necessary to prepare the Prototype of Special House for state Border Officer as a reference in Physical building development that concern to quality, local support, the spatial layout of the region, and local wisdom [2].

The Border Area that is determined to be the prototype object, namely: Entikong District, Sanggau Regency; West Kalimantan. Entikong is a sub-district in Sanggau District, West Kalimantan, Indonesia. Entikong has a land border route with Malaysian state especially Sarawak, so the land line is often called silk route because it can be passed directly by bus either from Indonesia or from Malaysia without having to through the river and sea, by therefore many migrant workers who come from Java and Sumatra who use the border of Entikong. The majority of tribes in Entikong Subdistrict are Dayak, Malay, Javanese, Batak, Padang, and others. The majority embraced Christianity Catholicism, Protestant Christianity, Islam, and Konghuchu. The livelihoods of the people are rice farmers, sahang (pepper), cocoa, rubber and part of the traditional gold mining.

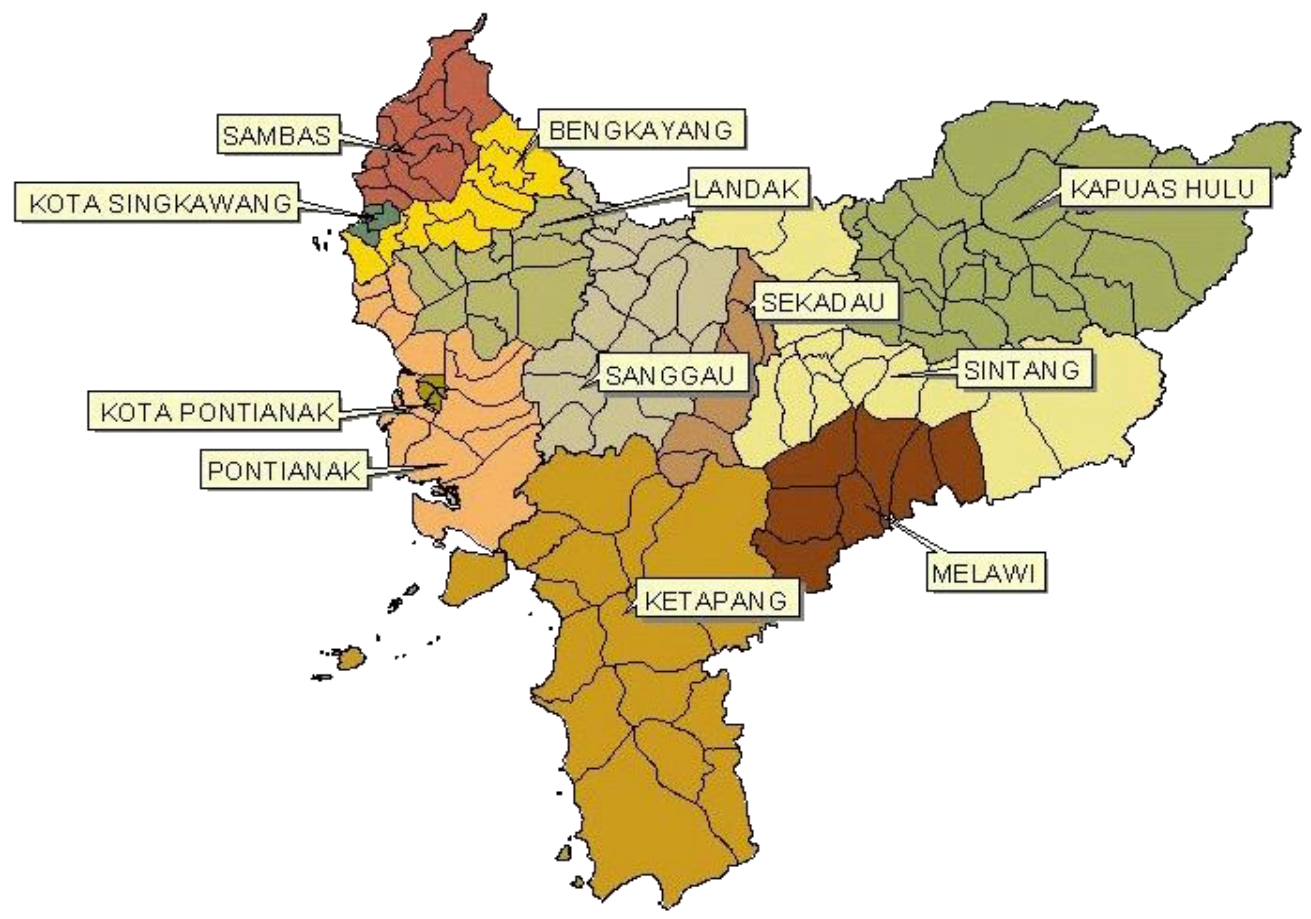




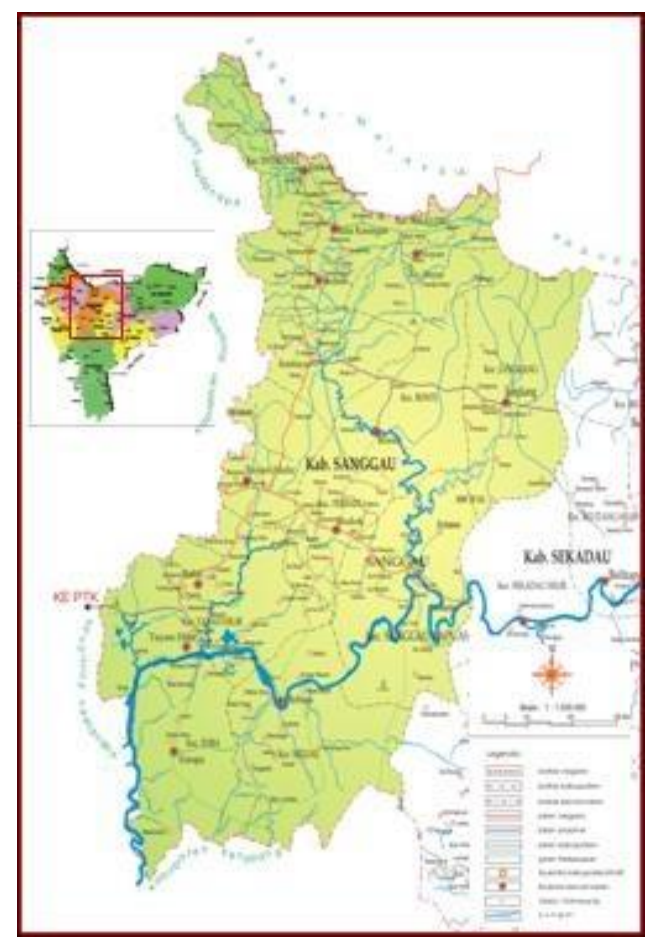

Fig. 1. Location of Sanggau Regency in West Kalimantan Province.

Entikong District is included in Sanggau District. Sanggau District is one of the Regions Level II in the province of West Kalimantan. Sanggau Regency is one of the areas located in the middle and located in the northern part of West Kalimantan province with an area of $12,857.70 \mathrm{~km}^{2}$ with a density of 29 people per $\mathrm{km}^{2}$. Seen from the geographical location of the sanggau district lies between $1^{\circ} 10^{\prime}$ North Latitude and $0^{\circ} 35^{\prime \prime}$ South and between Latitudes $109^{\circ} 45^{\prime}, 111^{\circ} 11^{\prime \prime}$ East Longitude [3]. This area is the birthplace of the current Governor of West Kalimantan, Cornelis M.H.

The border area in Sanggau Regency consists of 2 locations, Entikong located in Entikong Subdistrict and Balai Karangan in Sekayam Subdistrict. These two locations are located at the northernmost tip of Sanggau Regency which borders directly with Malaysia, precisely Sarawak border.

Entikong Subdistrict with sub district capital in Entikong village has an area of 506.89 $\mathrm{km} 2$ with population in 2006 is 12.828 Soul and Brutto density is 25 soul / km2. Administratively, Entikong District consists of 5 villages and 18 hamlets. This sub district is approximately $147 \mathrm{~km}$ from the capital of Sanggau Regency. The existing infrastructure consists of State road $14.5 \mathrm{~km}$, district road $41.7 \mathrm{~km}$, village road $83.37 \mathrm{~km}$. Available educational facilities consist of 1 unit of kindergarten, 18 units of elementary school, 2 units of junior school and 2 units of high school. Health facilities consist of 1 unit of public health center (puskesmas) and 1 unit of subsidiary puskesmas.

To get to Entikong from Pontianak, it can be reached by way of trans Kalimantan south axis to Tayan sub-district then cross to North pass Batang Tarang, Sosok, Kembayan and finally enter Entikong through trans Kalimantan road North axis. Trans Kalimantan road both 
south axis and north in general condition is good. Distance from Pontianak to Entikong 310 $\mathrm{km}$ with travel time is approximately 7 hours.

Basic facilities and infrastructure such as transportation, education, health, clean water, electricity, telecommunications, and economic facilities are still very limited. Until now, Entikong sub-district still has status as a lagging area. This condition resulted in the disparity of the welfare of the Entikong community with the Sarawak people. There are some areas that cannot be reached by land transportation (isolated area).

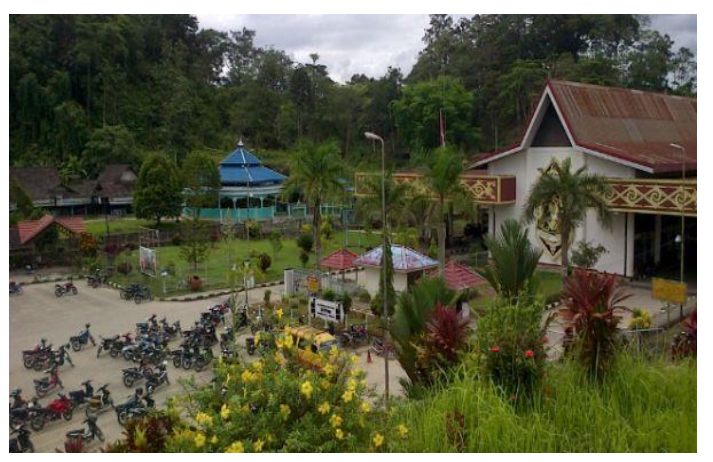

Fig. 2. Postal Area of Cross Country Inspection in Entikong.
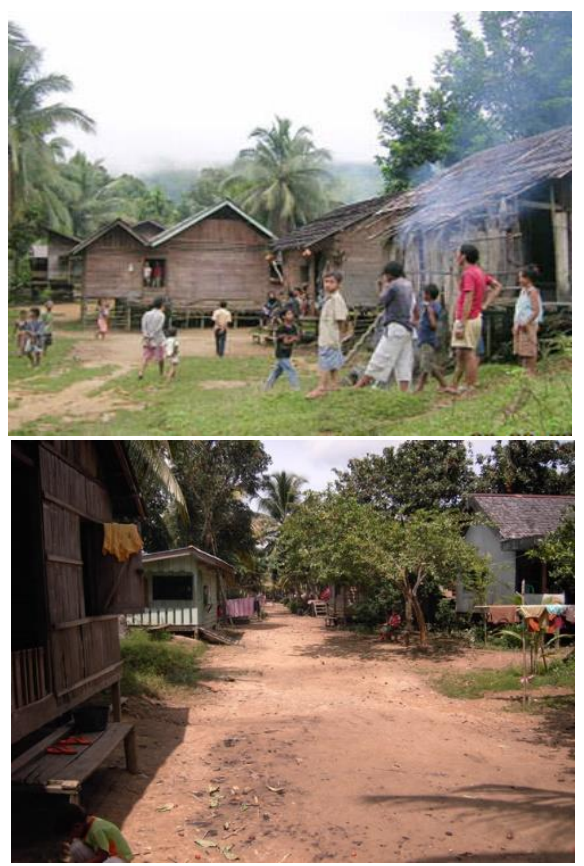

Fig. 3. Conditions of Entikong Housing [4]. 
The maxim of this research is the establishment of a prototype of a relief house on the border of the country, so that it can be a reference in the construction of Special Homes in the State Border which is appropriate as well as in a healthy, safe, and harmonious environment.

\section{Research Method}

The methodology used is by using quantitative method which is a method that describes the existing situation in the field by involving all stakeholders in the preparation of prototype special house. The data collected includes primary and secondary data. Then the data is analyzed by using qualitative approach that is to tell and explain the findings based on field survey.

The approach of study in this study is a qualitative approach that is an approach to conduct research that oriented on the symptoms of a natural phenomenon because of its orientation, so it is naturalistic and fundamental or initial and cannot be done in the laboratory yet must be conducted in the field. Therefore, this kind of research is called field study [5]. Implementation of this prototype preparation through the preparation stage includes focus group discussion activities with local government and vice custom leaders. The next stages are field survey activities to obtain data and information, public consultation, as well as preparation and discussion of planning concepts.

\section{Result and Discusion}

\subsection{Understanding the Concept of Local Wisdom}

Local wisdom in architecture can be seen from time and place that the local wisdom in terms of architecture comes from the past within the local people that carry out the value of local wisdom in persistent and continuous until now. Because the context of local wisdom applies to the local environment, based on local community thinking and who influence it, so that in each local wisdom to the other will be different and local in characteristic [6] and [2] So it needs a study of the wisdom of architectural locality regarding the wisdom values that can be applied in accordance with today conditions. Thus, architectural civilization is not trapped in the past, as science and architecture continue to evolve, automatically there will be changes in the development.

\subsection{Concepts of Philosophy and Traditional Intercultural Approach}

\subsubsection{House Architecture in Betang}

Each tribe in Indonesia has a characteristic form in the local architecture, known as a traditional house. Traditional house is the center of cultural networks, social relations, traditional law, prohibitions, myths, and religions covering all indigenous peoples. Traditional houses provide the main focus for the family and the community and which is the heart of the departure from its inhabitants for various activities. Traditional houses in Indonesia are not from architectural designs, yet most residents build their own homes or the local people work together with the direction of homeowners or carpenters [7]. 


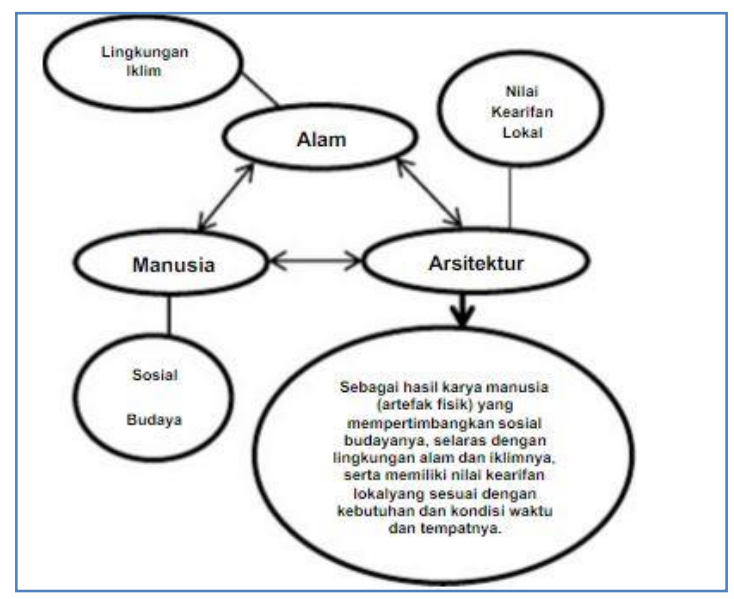

Fig. 4. Scheme of Human Relations, Nature, Architecture.

With few exceptions, the Indonesian archipelago share a custom of ancestral Austronesian ancestors in Taiwan 6000 years ago, and traditional Indonesian houses showcases some characteristics such as wood construction, the variety, and the elaboration of roof structures. The building that shows the early Austronesian style is a communal longhouse on stage, with tilted sloping roofs and heavy gable beams, as seen on the houses of Bataks and Tongkonan houses of Toraja. The diversity of the basic forms of long communal houses, among which are found among Dayak communities in Entikong, West Kalimantan; Sebatik, North Kalimantan; Sangihe, North Sulawesi; and Belu, East Nusa Tenggara. The type of longhouse is not found in Skouw Sae, Papua, because the people build houses with individual types [8].

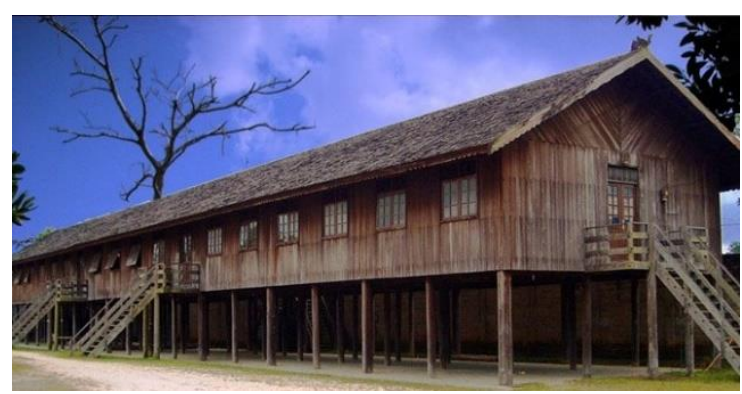

Fig. 5. Betang Houses.

The principles are on the poles, wood for gantry, and a straight door threshold system with wooden or bamboo walls which, without a load bearing, traditionally, instead of nails, mortis and tenon connections and wooden pegs are used. Natural materials such as wood, bamboo, ornamental roof, and fiber are traditional home ornament. Hardwood is generally used for pedestal and a combination of soft or hardwood is used for the upper wall without bearings and is often made of light wood or rumbia. Materials for woven roof is the leaves of palm leaf rumbia, alang-alang, or straw [9]. In every aspect of Dayak tribe life, there has always been based on the belief in the highest ruler who occupies two (2) nature that is the upper and lower 
realms, and humans are between the two realms. This view affects the division of traditional houses of Dayak tribe in general that is divided into 3 (three) buildings including head, body, and feet. The roof is analogous to the head, the wall as the body, and the foundation or column structure as the foot. In addition, the stage house system spontaneously expresses its selfconscious mental, which feels above and overcomes the nature so that it can be found a form of self-worth that is literally and figuratively over nature, the king against the fate of nature [10]. In principle, the division of Betang building is now the same as the previous Betang where the house is divided into 3 parts. But the distinguishes is the view that affects the division of the house, where in taking the form of the building is not based on the belief in religion but tries to utilize the wisdom and physical and technical benefits such as first, in healthy hygienic environment which not directly exposed to moisture and animals that disturbing and even dangerous[11]. Second, from building physics, it greatly protects the building against the ferocious tropical humidity and the building that easily decompose [10].

\subsubsection{Development of Betang House Architecture}

The Border House Prototype is accentuated on the House Betang Architecture based on its flexibility in accommodating the function of occupancy for the people in border region which will be inhabited by people from various kinds, tribes, and cultures of Indonesia. Rumah betang is taken as a blueprint of the design by combining elements of private and communal space, simplicity in building mass, and the ease of construction and architectural forms that suits the nature.

\subsubsection{Application Precedent on Plan}

The division of space is very simple which seen from the ground plan, in which the room is divided into 3 (three) parts, namely:

1. Batang Huma which consists of space and sleeping area,

2. Kitchen, and

3. Karayan, fruit storage and hunting stuff.

In the existing ground plan, it is transferred to 3 space zones, namely:

1. space for communal living, living room, family room, study room, dining room,

2. bedrooms which are private, and

3. service room for kitchen and toilet.

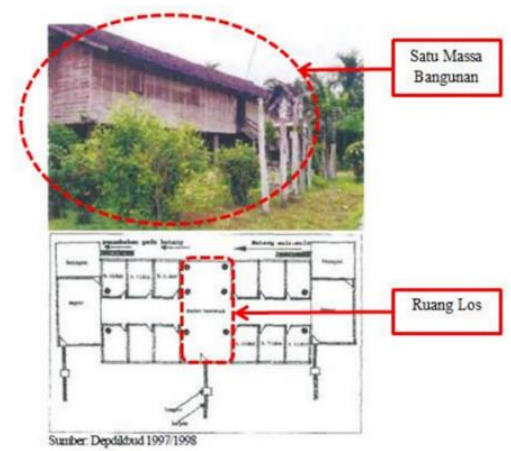

Fig. 6. The precedent for the building plan. 
From the above data, it produces Prototype Special House for the border state officers:

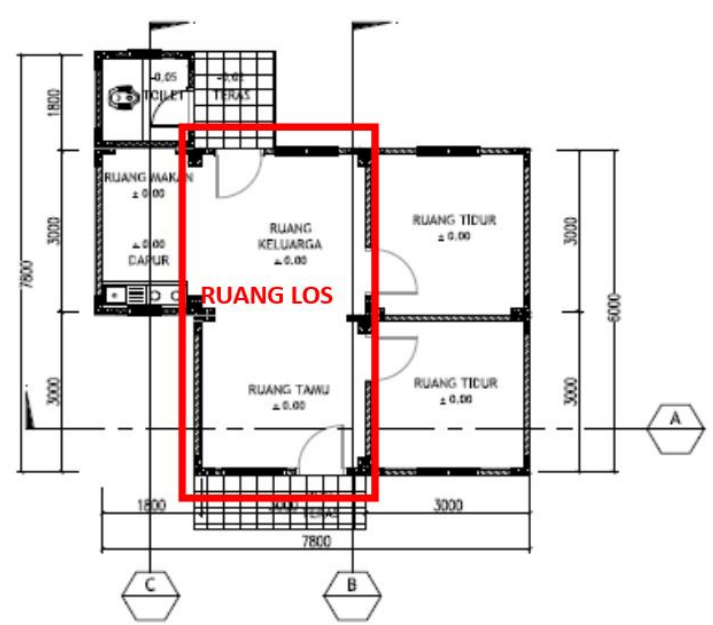

Fig. 7. Application on 45 Type plan.

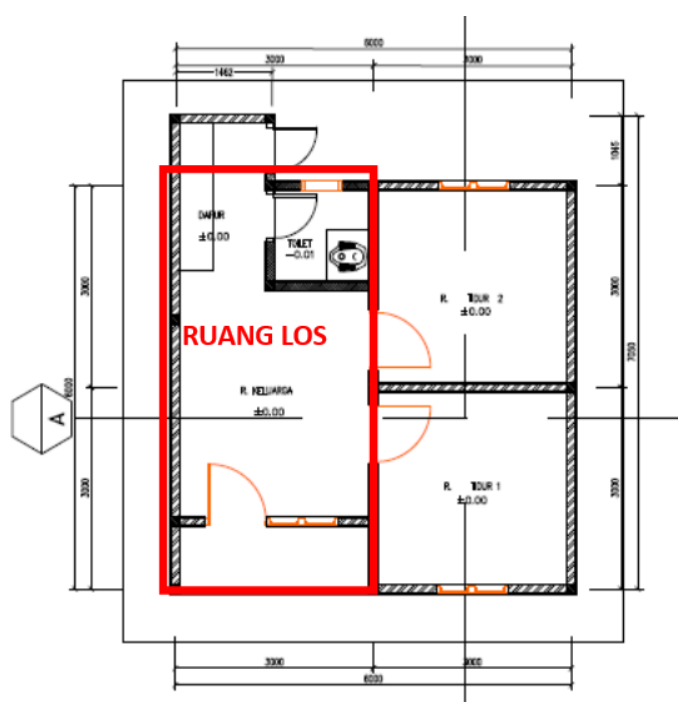

Fig. 8. Application on 45 Type plan.

Application Precedent on front view 


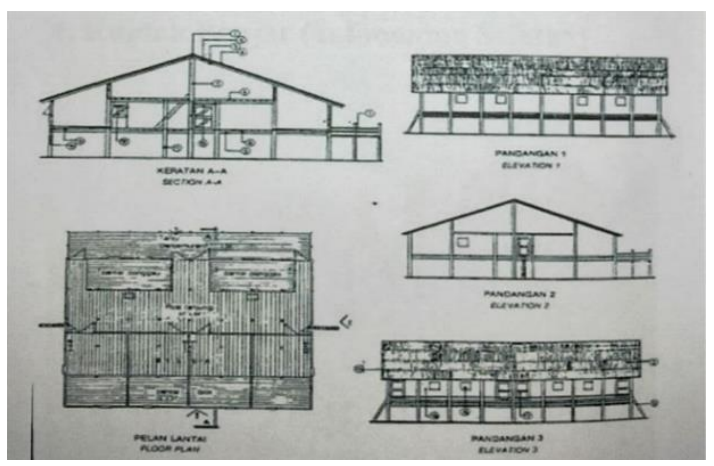

Fig. 9. View of traditional building of Rumah Bentang in West Kalimantan.

Precedents application in the form of building architecture include the use of a simple form of gable roof.
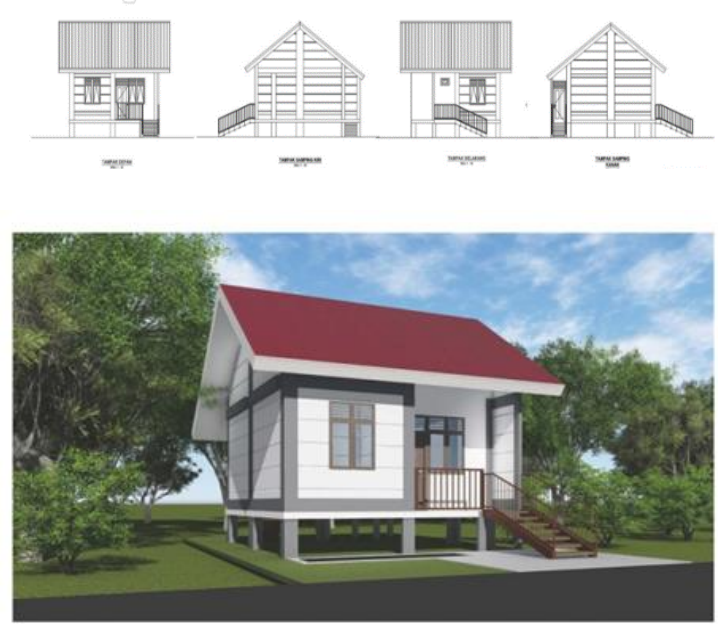

Fig. 10. Application view on the tilted house.

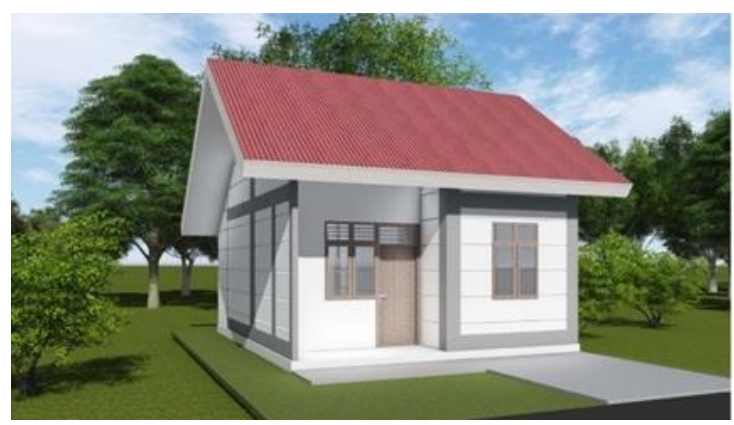

Fig. 11. Application view on the house. 


\subsection{Prototype Typology Concepts}

Prototype design concept refers to the Ideal concept. Insights, ideas, concepts, and scenarios are a continuum that can be an important basis for architecture. The concept integrates elements into one related whole and enables architects to devote their resources to the most important design aspects. Therefore, from various areas that have been studied then the prototype design is formulated. The prototype consists of several types applied in accordance with the wholeness and condition of the land, and the community.

1. Floor typology:

Type 45

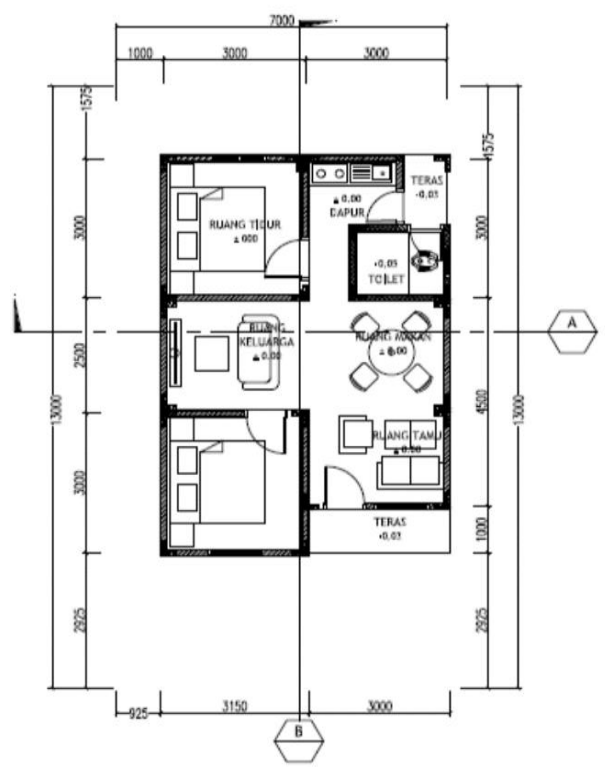

Type 36

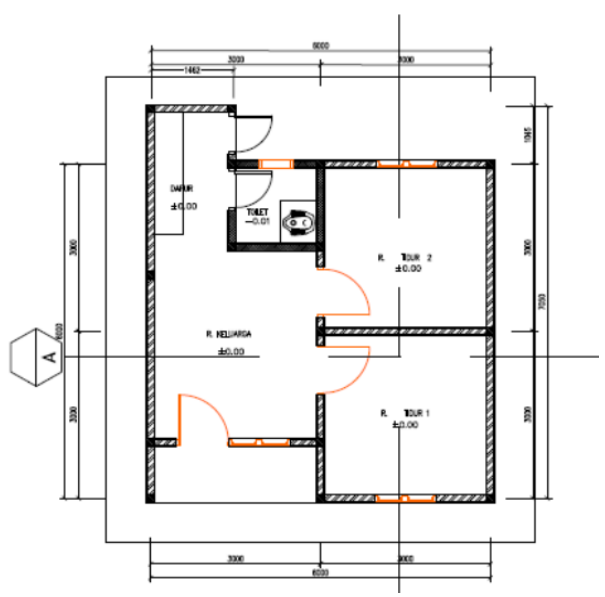


2. Structure typology [12]

Ground Land with Reinforced Concrete Structures:

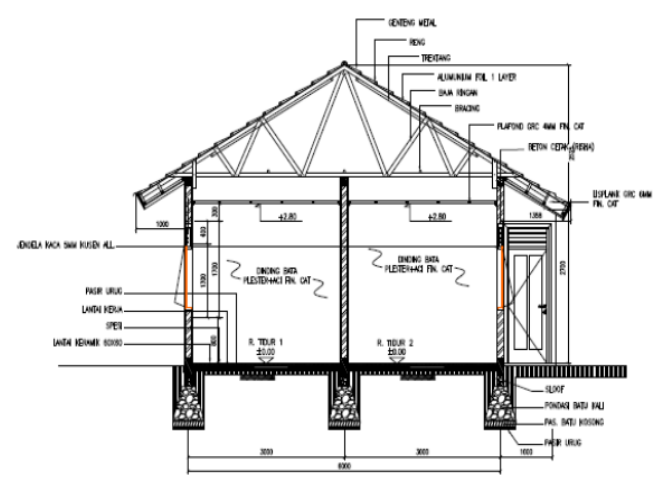

Stage with reinforced concrete structure:

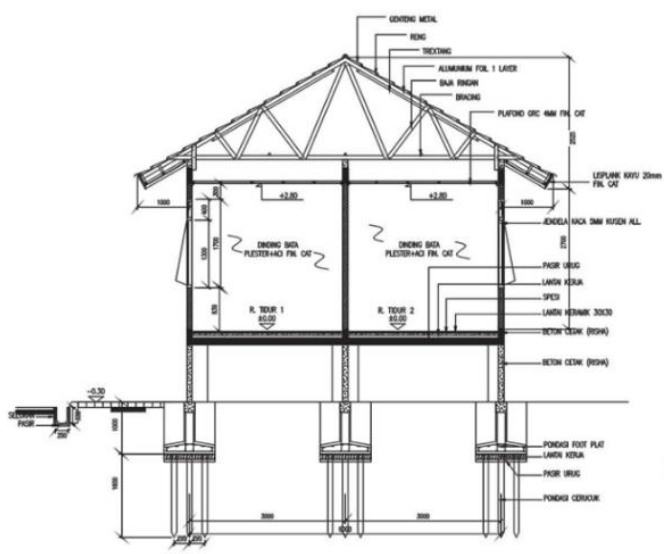

Stilt with wooden structure:

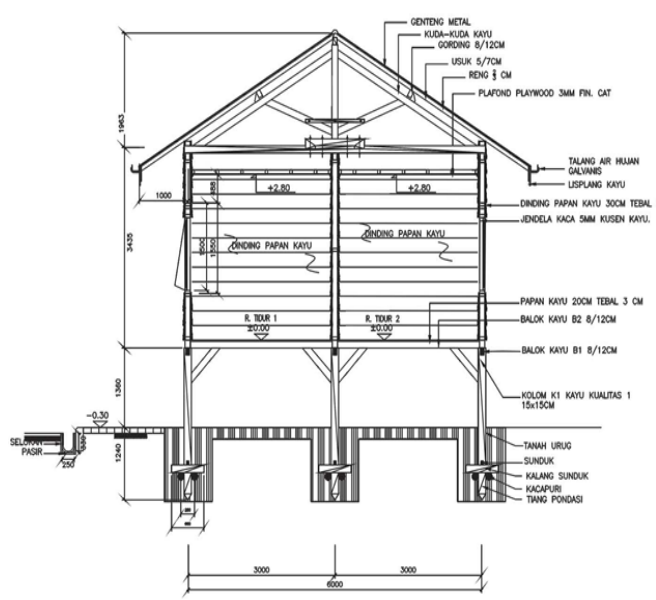


3. Typology plan:

a. Single

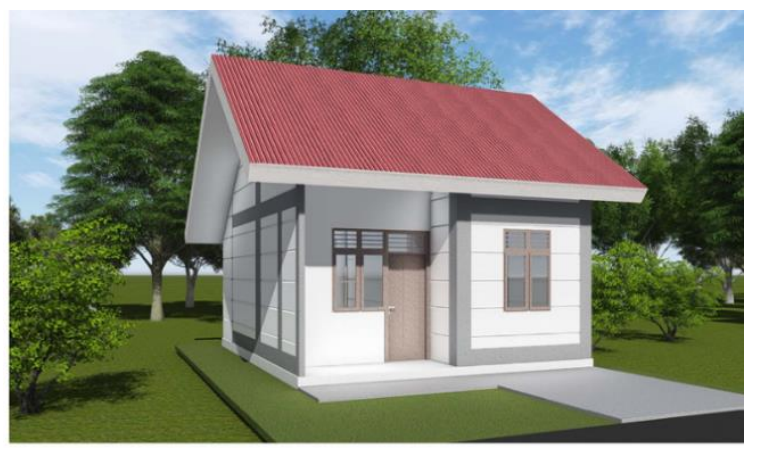

b. Row

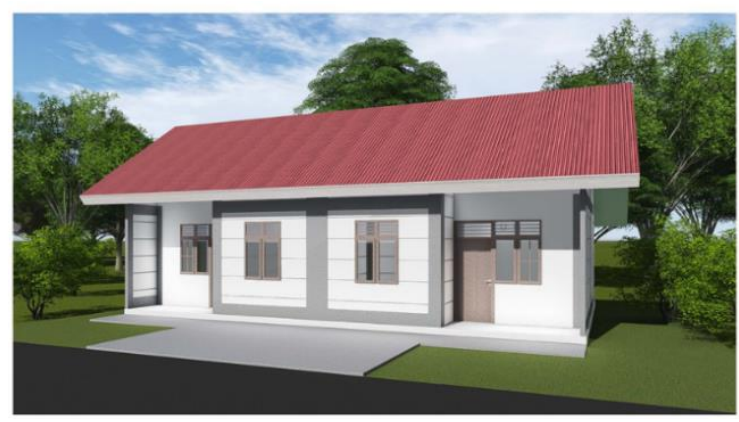

\subsubsection{Form Concepts}

The concept taken from the basic concept of Rumah Betang, simple house concept that accompanied by a line and 2 colors of natural monochromatic.

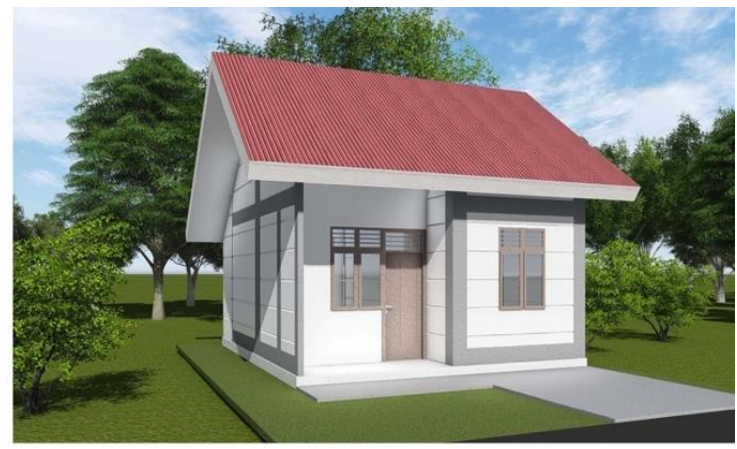




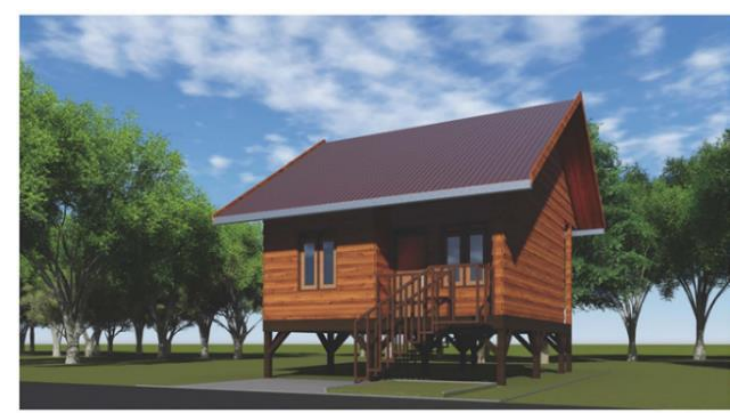

\subsubsection{Concept of Design Development}
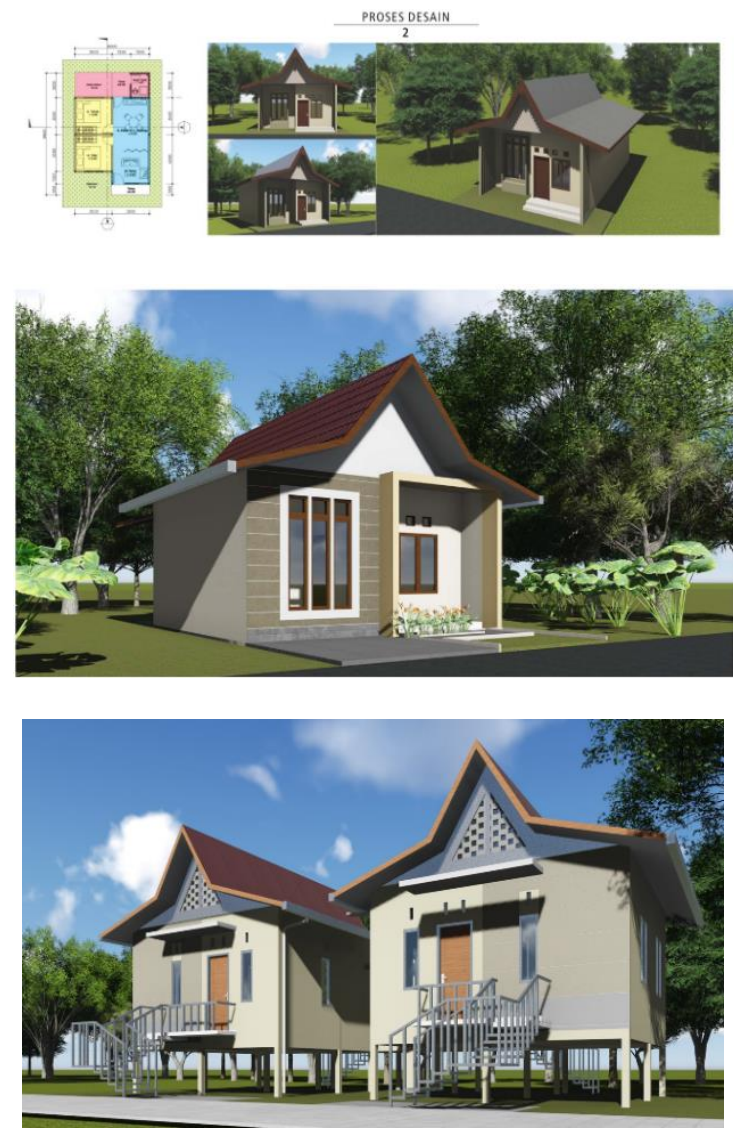

\section{Conclusion}

The conclusions of this study are as follows:

1. The design can be applied based on the precedent of local architecture. 
2. The design concerns to the needs of users in the field based on the field surveys conducted by planners.

3. Prototype of the border special house, in the future, it is expected to bring special feature or characteristics of the border regions in Indonesia

\section{Acknowledgments}

Gratitude to the Regional Government and Entikong District of Sanggau District who have allowed researchers to observe and collect data for the preparation of the Special House Prototype for the Indonesian-Malaysian border officers.

\section{References}

[1]Kementerian Perumahan Rakyat RI, Peraturan Menteri Perumahan Rakyat Nomor 10 tentang Pedoman Bantuan Pembangunan Rumah Khusus. 2013.

[2]K. L. Iskandar, Yulindiani, "Kearifan Lokal Dalam Penyelesaian Struktur Dan Konstruksi Rumah Rakit Di Sungai Musi - Palembang," Local Wisdom-Jurnal Ilm. Online, vol. Vol.2 No.2, pp. 37-45, 2010.

[3]BPS Kabupaten Sanggau, "Sosial dan Kependudukan,” 2016. .

[4]Retna Sujarwa, "Arsitektur, Manusia, dan Lingkungan," 2012. .

[5]M. Nazir, Metode Penelitian. Jakarta: Ghalia Indonesia, 1988.

[6]Antariksa Sudikno, "Kearifan Lokal dalam Arsitektur Perkotaan dan Lingkungan Binaan,” Malang, Jawa Timur, Indonesia, 2009.

[7]A. M. R. Muammar Ardli Hafiid, Antariksa, "Perubahan Ruang Pada Bangunan Rumah Panjae Suku Dayak Iban Kalimantan Barat,” J. RUAS, vol. Vol.13 No., pp. 37-47, 2015.

[8]Kanwil Departemen Pendidikan Dan Kebudayaan, Arsitektur Tradisional Daerah Kalimantan. 1997. [9]Parmonangan Manurung, "Local Wisdom Of Structure And Building System Traditional Architecture In Responding To Nature,” Int. J. Livable Sp., vol. Vol.2 No.1, 2017.

[10]Mangunwijaya, Wastu Citra. Jakarta: PT Gramedia Pusaka Utama., 1995.

[11]Ary Deddy Putranto, "Pengembangan Rumah Sederhana Sehat (Rsh) Menjadi Rumah Sederhana Sehat Berwawasan Lingkungan Di Kabupaten Malang,” J. RUAS, vol. Vol. 11 No, pp. 60-75, 2013.

[12]H. Frick, Ilmu Konstruksi Bangunan. Yogyakarta: Kanisius, 1997. 